\title{
Phases Reconstruction and Foaming Modification of Basic Oxygen Furnace Slag on Its Grindability
}

\author{
Ruiheng Xiang ${ }^{1}\left(\mathbb{D}\right.$, Ping Chen ${ }^{2,3,4}$, Rongjin Liu ${ }^{1,2,3, *}$, Cheng $\mathrm{Hu}^{2,3,4}$, Dandan Wan ${ }^{1}$, Jintao Fan ${ }^{1}$ \\ and Jiazhan Wei ${ }^{1,2,3}$ \\ 1 College of Materials Science and Engineering, Guilin University of Technology, Guilin 541004, China; \\ xiangruiheng2008@gmail.com (R.X.); currywd@163.com (D.W.); xuanxuan970924@126.com (J.F.); \\ andy412261183@163.com (J.W.) \\ 2 GuangXi Key Laboratory of New Energy and Building Energy Saving, Guilin University of Technology, \\ Guilin 541004, China; 2003124@glut.edu.cn (P.C.); hucheng42@glut.edu.cn (C.H.) \\ 3 Guangxi Engineering and Technology Center for Utilization of Industrial Waste Residue in Building \\ Materials, Guilin University of Technology, Guilin 541004, China \\ 4 College of Civil Engineering and Architcture, Guilin University of Technology, Guilin 541004, China \\ * Correspondence: liujin@glut.edu.cn; Tel.: +86-181-7832-6268
}

check for updates

Citation: Xiang, R.; Chen, P.; Liu, R.; Hu, C.; Wan, D.; Fan, J.; Wei, J. Phases Reconstruction and Foaming Modification of Basic Oxygen Furnace Slag on Its Grindability. Crystals 2021, 11, 1051. https:// doi.org/10.3390/cryst11091051

Academic Editor: Tomasz Sadowski

Received: 7 August 2021

Accepted: 24 August 2021

Published: 1 September 2021

Publisher's Note: MDPI stays neutral with regard to jurisdictional claims in published maps and institutional affiliations.

Copyright: (c) 2021 by the authors. Licensee MDPI, Basel, Switzerland. This article is an open access article distributed under the terms and conditions of the Creative Commons Attribution (CC BY) license (https:// creativecommons.org/licenses/by/ $4.0 /)$.

\begin{abstract}
Basic oxygen furnace (BOF) slag is a main byproduct produced during the converter steelmaking process. The poor grindability of BOF slag limits its added-value application. In this paper, the grinding characteristics of unmodified and reconstructed BOF slag were compared. Additionally, the grinding property of reconstructed steel slag was also studied after $\mathrm{SiC}$ foaming. The results show that the solid solution of divalent metal oxides' RO phase, considered as the hardly grinding phase, discomposes after lime-bauxite reconstruction. The characteristics of BOF slag were tested through particle size analysis, XRD, SEM and MIP. The SSA (specific suface area) and the particle diameter of unmodified BOF slag could reach $303.1 \mathrm{~m}^{2} / \mathrm{kg}$ and $51.75 \mu \mathrm{m}$ after $10 \mathrm{~min}$ of grinding, but that of reconstructed BOF slag could reach $354.5 \mathrm{~m}^{2} / \mathrm{kg}$ and $18.16 \mu \mathrm{m}$ after the same grinding time, respectively. The grinding efficiency of steel slag was obviously increased and the particle characteristics were improved after foaming modification. BOF formed as a porous structure after $\mathrm{SiC}$ foaming; its porosity, SSA, and particle diameter can reach $31.79 \%, 424.4 \mathrm{~m}^{2} / \mathrm{kg}$, and $24.36 \mu \mathrm{m}$ and increased by $10.31 \%, 19.72 \%$, and $39.04 \%$, compared with the reconstructed steel slag of undoped foaming agent, respectively, and the grindability was further improved. A theoretical basis for large-scale BOF slag utilization is provided.
\end{abstract}

Keywords: reconstruction; grindability; $\mathrm{SiC}$; foaming agent; particle size analysis; mercury intrusion porosimetry

\section{Introduction}

Portland cement production is known to be highly energy intensive (5.3 MJ $/ \mathrm{kg}$ embodied energy for ordinary silicate cement production [1]) and is a significant contributor to greenhouse gas emissions $\left(0.97 \mathrm{t} \mathrm{CO}_{2} / \mathrm{t}\right.$ OPC [1]). It is estimated that Portland cement production accounts for nearly $7 \%$ of the total global $\mathrm{CO}_{2}$ emissions annually [2,3]. Therefore, $\mathrm{CO}_{2}$ gas emissions from cement and concrete production are becoming a global concern, and many researchers are working on the development of silicate cement substitutes to produce less environmentally damaging cementitious materials.

In recent years, increasing attention has been paid to the use of waste and by-products from industrial production as a partial solution to environmental and ecological problems. Basic oxygen furnace (BOF) slag is an industrial solid waste generated in the steelmaking process $[4,5]$. It is rich in $\mathrm{CaO}, \mathrm{SiO}_{2}, \mathrm{Al}_{2} \mathrm{O}_{3}, \mathrm{Fe}_{2} \mathrm{O}_{3}$ in chemical compositions, and the mineral phases of steel slag are mainly composed of $\mathrm{C}_{3} \mathrm{~S}, \mathrm{C}_{2} \mathrm{~S}, \mathrm{C}_{2} \mathrm{~F}, \mathrm{C}_{4} \mathrm{AF}$, and the solid solution of divalent metal oxides $\mathrm{RO}$ phase. Based on its chemical and mineral compositions, $\mathrm{BOF}$ 
slag has potential hydration activity [4]. Much research has shown that finely milled (BOF) slag can be used as a cement replacement in mortars and concretes [6-8]. However, BOF has poor grindability. BOF slag requires a longer grinding time than cement clinker [5], due to its high content of iron oxide and RO phase and the relatively high absolute density (about $3.7 \mathrm{~g} / \mathrm{cm}^{3}$ on average). The iron and manganese ions have a great affinity for oxygen because of their strong polarization ability. These ions combine with oxygen in the silicon-oxygen tetrahedron; its tetrahedral structure is destroyed and the interconnection of the silicon-oxygen tetrahedrons is promoted, thus a complex and huge island chain of silica groups is formed. These interconnected silica-oxygen groups are hard to destroy under the impact of mechanical force. What's more, the surface energy of the fine BOF slag particles increases obviously, as the SSA increases to a certain extent, and the particles show a trend of agglomeration [6], resulting in BOF slag being difficult to be ground. So that the grinding efficiency of BOF slag is low and the energy consumption is great $[9,10]$.

For this reason, some studies were done to improve the grindability and grinding efficiency of BOF slag. At present, the research on improving the grinding efficiency of steel slag is mainly focused on the optimization of grinding equipment such as vertical mill and ball mill, but there are few studies on other measures such as removing the hard grinding phase (HGP) or using chemical admixtures [11]. Although vertical mill has been used in the grinding of steel slag, many application studies show that the shape of steel slag powder prepared by vertical mill is poor, and presents as flat, needle, and irregular shapes. Therefore, the preparation of steel slag powder in China is still dominated by a ball mill. At the same time, some studies show that the metal iron in steel slag is one of the main reasons for the poor grindability of steel slag [11]. However, in different milling stages, the factors affecting the milling efficiency usually vary with different milling characteristics [12].

The RO phase with the highest density is the hardest component in the mineral composition of steel slag. The higher the molar ratio of $\mathrm{FeO} / \mathrm{MgO}$, the higher the hardness and density of the RO phase are, and the worse the grindability of steel slag is. The higher the $\mathrm{FeO} / \mathrm{MgO}$ molar ratio, the stronger the magnetic properties and the higher electrical conductivity of the $\mathrm{RO}$ phase are, so the better beneficiation selectivity of electric separation and magnetic separation are. The separation of the RO phase from steel slag cannot only improve the grindability of steel slag, but also increase the relative content of silicate minerals and eliminate the inherent defects of low active minerals in steel slag [13]. A new mineral phase of wollastonite $\left(\mathrm{CaO} \cdot \mathrm{SiO}_{2}\right)$ and a small number of vitreous phases were generated by adding fly ash into steel slag before quenching. The proportion of accumulated slag with particle size less than $75 \mu \mathrm{m}$ and $250 \mu \mathrm{m}$ increased from $13.3 \%$ and $16.1 \%$ to $36.9 \%$ and $83.8 \%$, respectively, when fly ash content changed from $0 \mathrm{wt} \%$ to $30 \mathrm{wt} \%$ [14], and the grindability was improved. The previous research of our group took the hot stuffing BOF slag of Guangxi Liugang Co., Ltd. as the research object, and proposed to separate the RO phase by adding $\mathrm{CaO}$ and $\mathrm{Al}_{2} \mathrm{O}_{3}$ based on its characteristics of replacement solid solution, which may improve the grindability of BOF slag [15].

In other fields, some researchers have carried out research on the influence of pore structure on grindability, which provides certain ideas for the research of this paper. Wang Qing et al. [16] studied the influence of microwave drying on the physical and chemical properties of Liushuhe oil shale on the development of pores due to different heating mechanisms. Moisture transfer was produced by microwave drying, resulting in a water vapor pressure gradient between the surface and the inside of the material, and a large number of micropores $(<2 \mathrm{~nm})$ forming mesopores $(2 \mathrm{~nm}-50 \mathrm{~nm})$. Microwave drying has a $40 \%$ higher grindability index than ordinary drying. Qin Y.H. et al. [17] proposed a novel high-voltage pulse discharge (HVPD) pretreatment method to weaken the mechanical properties of magnetite shale and improve its grinding efficiency. The HVPD pretreatment product has a large specific surface area, a large total pore volume, many pores, a loose structure, and a larger porosity than the mechanically crushed product. The mass fraction of the milled products small than $0.074 \mathrm{~mm}$ pre-treated by HVPD is more than that of mechanical pulverization. 
In this paper, a new solution method for slag grinding was introduced. The tempering component and foaming agent was added to the steel slag, the slag phase composition and structure was changed, and its grindability was improved.

\section{Raw Materials and Methods}

\subsection{Raw Materials}

BOF slag was supplied from Liuzhou Iron \& Steel Co., Ltd. (Liuzhou, China), PO42.5 cement clinker was the reference cement obtained from China Building Academy Co., Ltd. (Beijing, China), Soft burnt lime and bauxite were used as composition tempering materials from the factory in Guilin Jinshan Chemical Industrial Co., Ltd. (Guilin, China) and Hengxian Shaodong Chemical Industrial Co., Ltd. (Nanning, Chna), respectively. Silicon Carbide ( $\mathrm{SiC}$ ) produced by Xilong Scientific Co., Ltd (Shantou, China). was used as the foaming agent. In the preprocessing stage, steel slag, Portland cement clinker and composition adjusting materials were dried at $383 \mathrm{~K}$ in a drying cabinet for $8 \mathrm{~h}$ at first, and then were ground to a Blaine SSA of $400 \pm 20 \mathrm{~m}^{2} / \mathrm{kg}$. The main chemical components of raw materials tested by chemical titration are shown in Table 1 .

Table 1. Chemical composition of raw materials (wt \%).

\begin{tabular}{ccccccccccc}
\hline Raw Materials & $\mathbf{S i O}_{2}$ & $\mathbf{A l}_{\mathbf{2}} \mathbf{O}_{\mathbf{3}}$ & $\mathbf{F e}_{\mathbf{2}} \mathbf{O}_{\mathbf{3}}$ & $\mathbf{C a O}$ & $\mathbf{M g O}$ & $\mathbf{S O}_{3}$ & $\mathbf{N a}_{\mathbf{2}} \mathbf{O}$ & $\mathbf{K}_{\mathbf{2}} \mathbf{O}$ & $\mathrm{TiO}_{\mathbf{2}}$ & $\mathbf{L o s s}$ \\
\hline Steel slag & 16.46 & 6.20 & 20.11 & 43.46 & 6.83 & 0.34 & 0.04 & 0.33 & - & - \\
Cement clinker & 22.04 & 5.73 & 2.86 & 62.05 & 1.33 & 2.91 & - & - & - & 1.50 \\
Lime & 0.15 & 1.03 & 0.49 & 97.25 & 0.25 & - & - & - & - & 1.22 \\
Bauxite & - & 90 & 1.5 & 0.2 & 0.2 & 4.64 & - & - & 3 & 0.46 \\
\hline
\end{tabular}

From Table 1, the contents of $\mathrm{CaO}, \mathrm{SiO}_{2}$, and $\mathrm{Al}_{2} \mathrm{O}_{3}$ in the original steel slag were not as high as in cement. The content of $\mathrm{CaO}$ in steel slag was about $43.46 \%$, for instance, while it's about $62.05 \%$ in cement. The $\mathrm{C} / \mathrm{S}\left(\mathrm{CaO} / \mathrm{SiO}_{2}\right)$ of steel slag was 2.64 , but the $\mathrm{C} / \mathrm{S}$ of cement was 2.81. It was obvious that the chemical composition of steel slag was different from cement.

\subsection{Method}

The steel slag powder, limestone, bauxite, and $\mathrm{SiC}$ were prepared according to different test ratios. The mixture was then homogenized for $2 \mathrm{~h}$ in the mixing bucket to make it fully uniform, then pressed into the test tablet by a powder tablet machine. The test tablet was calcined at $1290^{\circ} \mathrm{C}$ in a muffle furnace. After sintering to the specified holding time, it was quenched to make the required steel slag.

The density of pretreated raw materials was determined according to Chinese National Standard GB/T 208-2014 [18], and SSA was tested according to Chinese National Standard GB/T 8074-2008 [19]. The mineralogical phase of raw materials and reconstructed steel slag were determined by powder XRD, using a PANalytical (Almelo, Netherland) X'Pert Pro diffractometer with nickel-filtered $\mathrm{Cu} \mathrm{K} \alpha_{1}$ radiation, a scanning speed of $12^{\circ} / \mathrm{min}$, and a scanning range of $10^{\circ}$ to $80^{\circ}$. The steel slag mineral morphology was observed by a Hitachi (Tokyo, Japan) S4800 scanning electron microscope (SEM). The Pore structure of BOF slag was tested by a Micromeritics AutoPore IV 9510 Mercury Intrusion Porosimeter under 60000 psi.

\section{Results and Discussion}

\subsection{Reconstruction}

Lime and bauxite were selected as tempering components to reconstruct the BOF slag at a high temperature of $1290{ }^{\circ} \mathrm{C}$ according to previous study [20], in order to increase the content of $\mathrm{C}_{2} \mathrm{~S}$ and $\mathrm{C}_{4} \mathrm{AF}$ as the main mineral components of BOF slag and reduce the content of the RO phase. The specific mixing ratio is shown in Table 2. 
Table 2. Mix ratio of BOF slag reconstruction.

\begin{tabular}{cccc}
\hline Sample & BOF Slag & Lime & Bauxite \\
\hline RS & 75 & 21 & 4 \\
\hline
\end{tabular}

The X-ray diffraction of reconstructed BOF slag (RS) and original BOF slag (OS) is shown in Figure 1. The main mineral phases of BOF slag are $\alpha$-dicalcium silicate $\left(\alpha-C_{2} S\right)$, $\beta$-dicalcium silicate $\left(\beta-C_{2} S\right)$, dicalcium ferrite $\left(C_{2} F\right)$, tetracalcium ferroaluminate $\left(C_{4} A F\right)$, and other cementitious mineral phases, as well as non-gelling magnetite $\left(\mathrm{Fe}_{3} \mathrm{O}_{4}\right)$ and the $\mathrm{RO}$ phase. It can be seen that the characteristic peaks of $\mathrm{C}_{2} \mathrm{~S}$ and $\mathrm{C}_{4} \mathrm{AF}$ in the reconstructed BOF slag increase with the addition of tempering components, indicating that the addition of tempering components promotes the increase of the $\mathrm{C}_{2} \mathrm{~S}$ and $\mathrm{C}_{4} \mathrm{AF}$ content. $\mathrm{C}_{2} \mathrm{~S}$ and $\mathrm{C}_{4} \mathrm{AF}$ exhibit good hydration activity and grindability in cement clinker, and the properties of BOF slag will be improved with the increase of their contents. At the same time, the characteristic peak of the RO phase disappeared, and the characteristic $\mathrm{C}_{4} \mathrm{AF}$ peak appeared. It shows that with the addition of tempering and tempering components, the $\mathrm{RO}$ phase in the steel slag is precipitated and decomposed; partly converted into $\mathrm{MgFe}_{2} \mathrm{O}_{4}$, and partly converted into iron phases.

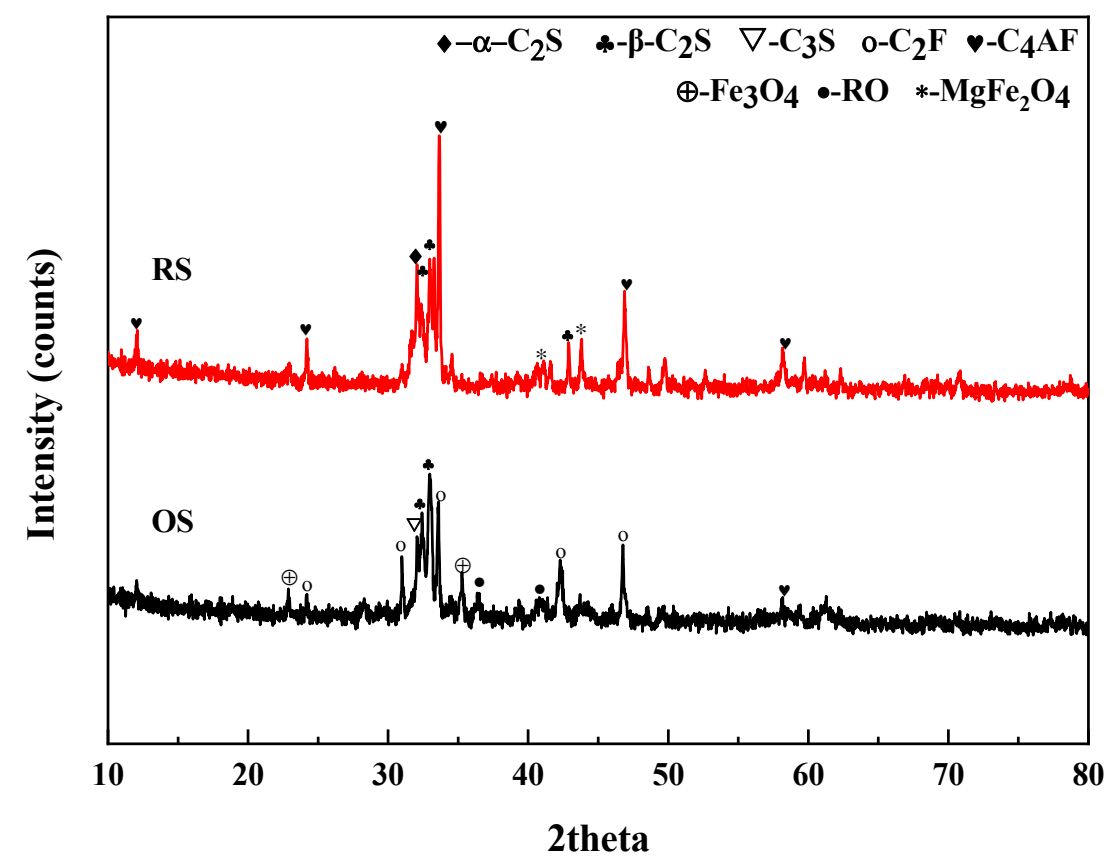

Figure 1. X-ray diffraction of BOF slag before and after reconstruction.

Unmodified BOF slag and reconstructed BOF slag were ground for $10 \mathrm{~min}$ by vibrating mill, respectively, the SSA and particle distribution of BOF slag are tested, and the results are as follows. It can be seen from Figure 2. that the small-size particles in the BOF slag increase, while the large-size particles are less after high-temperature reconstruction. The average particle size of the BOF slag is reduced from $51.75 \mu \mathrm{m}$ to $39.96 \mu \mathrm{m}$ as plotted in Figure 2. Meanwhile, the SSA of the fine powders prepared by the reconstructed slag and the unmodified steel slag under the same grinding time was studied. It is found that the SSA of the reconstructed steel slag powder increased from $303.1 \mathrm{~m}^{2} / \mathrm{kg}$ of the unmodified steel slag to $354.5 \mathrm{~m}^{2} / \mathrm{kg}$ as shown in Table 3, which fully shows that the grindability of the reconstructed steel slag modified by the calcium-aluminum composition is better than that of the unmodified converter steel slag. 


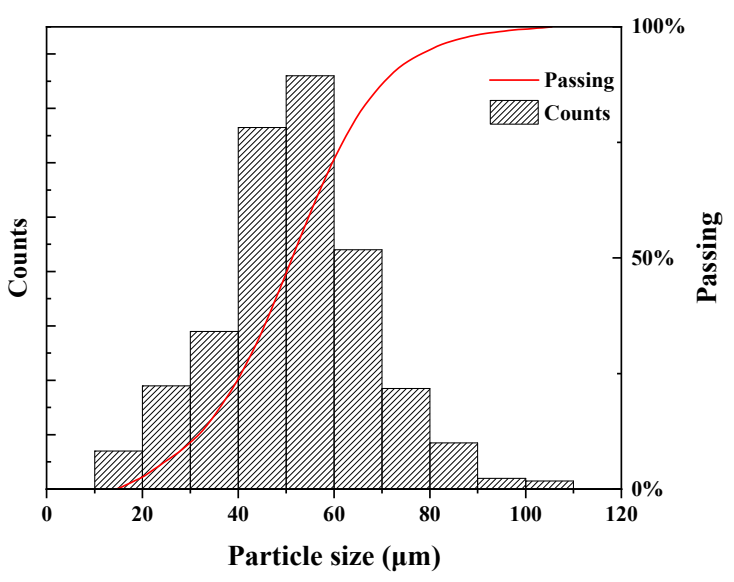

(a)

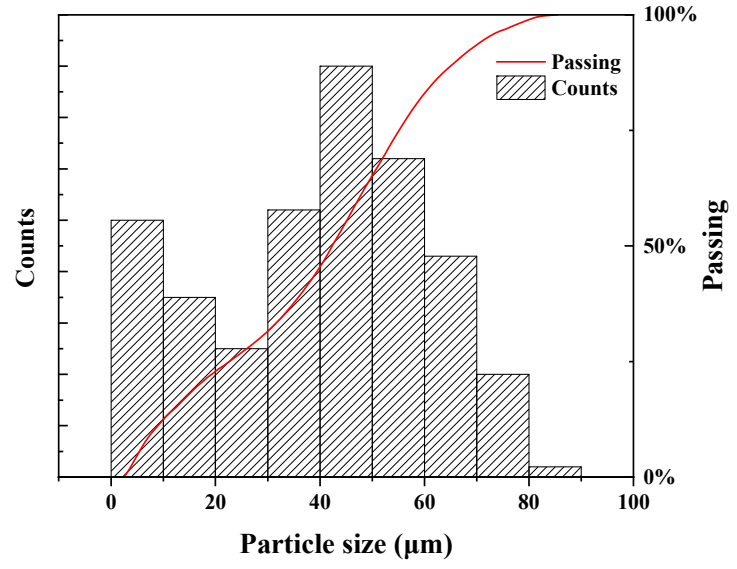

(b)

Figure 2. Particle distribution of steel slag before and after reconstruction. (a) Original BOF slag; (b) Reconstructed BOF slag.

Table 3. SSA of original steel slag powder and reconstructed steel slag powder.

\begin{tabular}{cc}
\hline Sample & SSA ( $\left.\mathbf{m}^{2} / \mathbf{k g}\right)$ \\
\hline OS & 303.1 \\
\hline RS & 354.5 \\
\hline
\end{tabular}

As the XRD analysis mentions above, a mass of $\mathrm{C}_{2} \mathrm{~S}$ and other silicate phases with good grindability are newly formed, with the addition of the tempering components. $\mathrm{Fe}$ also transforms from a metal oxide solid solution-RO phase, and combines with calcium ferrite into a combined state of $\mathrm{C}_{4} \mathrm{AF}$. The content of calcium ferrite and the RO phase in $\mathrm{BOF}$ slag is reduced in the process of high-temperature reconstruction. The content of the calcium ferrite phase and the RO phase in BOF slag decrease in the process of high temperature modification, and these two phases are also the most difficult to grind from the perspective of mineral hardness [12]. Therefore, the grindability of steel slag is improved after high-temperature reconstruction treatment due to the changes of these two factors.

\subsection{SiC Foaming Modification}

In the research of the previous chapter of this article, it can be found that the grindability of BOF slag is improved to a certain extent by high-temperature reconstruction, but it is still not ideal. This chapter describes a method by which a high-temperature foaming agent, $\mathrm{SiC}$, is added to a high-temperature slag reconstruction process for further improvement of the grindability of slag from the structure. $\mathrm{SiC}$ begins to react at about $1000^{\circ} \mathrm{C}$, which is mainly the oxidation reaction as Equation (1), and the reaction continues with the increase in temperature. This reaction will result in a weight gain of the solid phase, and result in a weight increase of $50 \mathrm{wt} \%$ theoretically, when the $\mathrm{SiC}$ is completely converted to $\mathrm{SiO}_{2}$. In practice, however, $\mathrm{SiC}$ begins to gain weight at around $1000{ }^{\circ} \mathrm{C}$, but it increases slowly, and its weight gain is only $2.2 \mathrm{wt} \%$ at $1300{ }^{\circ} \mathrm{C}$, which means that only $4.4 \%$ of $\mathrm{SiC}$ has undergone oxidation. Studies have found [21] that $\mathrm{SiO}_{2}$ formed by the oxidation of $\mathrm{SiC}$ will form a dense oxide layer on the surface of $\mathrm{SiC}$, blocking the continued reaction of $\mathrm{SiC}$.

$$
\mathrm{SiC}(\mathrm{s})+2 \mathrm{O}_{2}(\mathrm{~g}) \rightarrow \mathrm{SiO}_{2}(\mathrm{~s})+\mathrm{CO}_{2}(\mathrm{~g}) \Delta \mathrm{G}=-801.23 \mathrm{~kJ} \cdot \mathrm{mol}^{-1}
$$

In this chapter, $0.4 \%, 0.8 \%, 1.2 \%, 1.6 \%$, and $2 \%$ of the $\mathrm{SiC}$ foaming agent micro powder is added to the basic ratio of $\mathrm{BOF}$ slag reconstruction to further improve the grindability of the BOF slag. The sintering temperature is set to $1290^{\circ} \mathrm{C}$, the holding time is set to $90 \mathrm{~min}$, 
and the cooling system adopts air-cooling and rapid quenching. The specific configuration is shown in the Table 4 below.

Table 4. Mix ratio of $\mathrm{SiC}$ foaming porous reconstructed steel slag.

\begin{tabular}{ccccc}
\hline \multirow{2}{*}{ Sample } & \multicolumn{3}{c}{ wt \% } \\
\cline { 2 - 5 } & BOF Slag & Lime & Bauxite & SiC \\
\hline PRS1 & & & & 0.4 \\
PRS2 & & & 4 & 0.8 \\
PRS3 & 75 & & & 1.2 \\
PRS4 & & & & 1.6 \\
PRS5 & & & & 2 \\
\hline
\end{tabular}

Since $\mathrm{SiC}$ is surrounded by silicate forming components or liquid phases under hightemperature alkaline molten salt conditions, the silica protective layer reacts with the alkaline molten salt to form a silicate liquid phase, causing corrosion or cracking of the protective layer. The rapid diffusion of oxygen through the protective layer causes the chemical reaction between $\mathrm{SiC}$ and oxygen to increase greatly, and a large amount of $\mathrm{CO}_{2}$ and $\mathrm{CO}$ gas is generated [20]. The oxidation was schematic as shown in Figure 3. The generated gas was not discharged to the outside in time, remained in the test cake, and caused closed cells. In turn, the test cake was deformed, the pressure of the blocked pore gas was higher than the capillary pressure, and the test cake swelled as a result. The sintering process of this material is expressed by the following equation [22], in which $\varepsilon$ is porosity, $\eta_{\mathrm{s}}$ is the effective viscosity of the system, $\mathrm{P}_{\mathrm{c}}$ is the capillary pressure produced in the fine pores of the piece, and $\mathrm{P}_{\mathrm{g}}$ is the pressure that the gas inside the pores exerts.

$$
\frac{-\mathrm{d} \varepsilon}{\varepsilon \mathrm{dt}}=\frac{3}{4 \eta \mathrm{s}}(\mathrm{Pc}-\mathrm{Pg})
$$

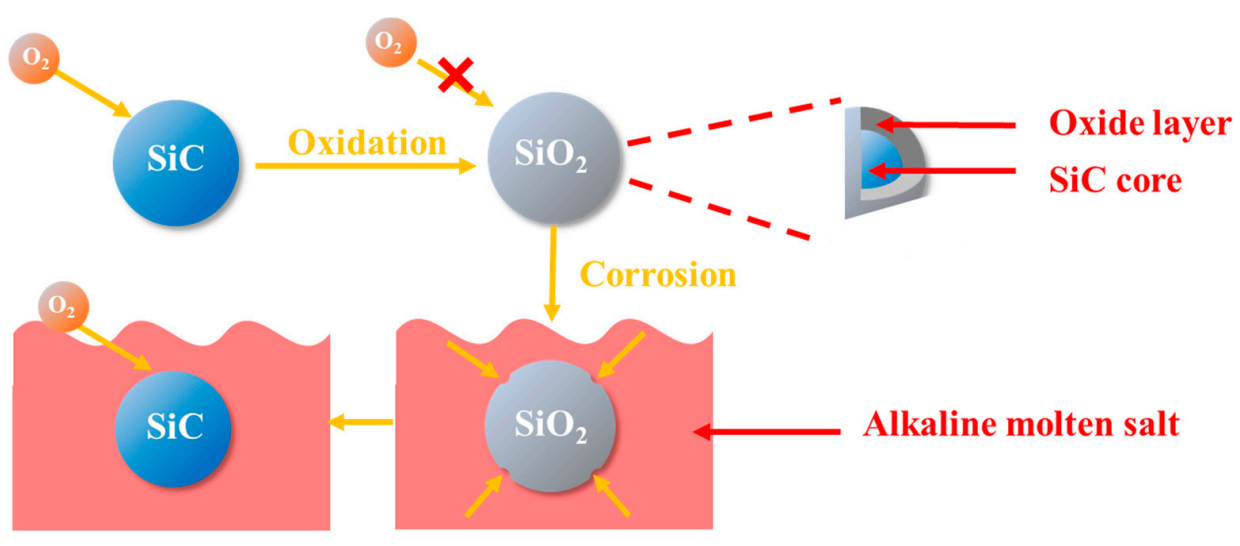

Figure 3. Schematic diagram of $\mathrm{SiC}$ oxidation.

The SEM micrographs of the reconstructed steel slag and the porous restructured steel slag containing $1.6 \% \mathrm{SiC}$ produced by sintering at $1290^{\circ} \mathrm{C}$ are shown in Figure 4 . The reconstructed steel slag not doped with $\mathrm{SiC}$ presents a relatively dense microstructure with fewer pores, while those structure with the addition of $\mathrm{SiC}$ as a high-temperature foaming agent become looser, and the pore size increases. The sample contains many isolated spherical closed pores with an average pore diameter of about $10 \mu \mathrm{m}$, and there are also long and narrow open pores, when the $\mathrm{SiC}$ mass fraction is $1.6 \%$, as shown in Figure $4 \mathrm{~b}$.

In fact, $\mathrm{SiC}$ particles are easily oxidized at high temperatures when they are exposed to $\mathrm{O}_{2}$ [23]. Nevertheless, the formation of a dense $\mathrm{SiO}_{2}$ protective film on the surface of $\mathrm{SiC}$ particles can effectively prevent their further oxidation [24]. Flux oxides (ie, $\mathrm{K}_{2} \mathrm{O}$, $\mathrm{Na}_{2} \mathrm{O}$, and $\mathrm{CaO}$, etc.) have been found that have a significant corrosive effect on the $\mathrm{SiO}_{2}$ 
protective film. The addition of quenching and tempering components such as $\mathrm{CaO}$ and $\mathrm{Al}_{2} \mathrm{O}_{3}$, meanwhile, reduces the viscosity of the system and makes the BOF slag in the molten liquid phase form at a lower temperature. The formation of more liquid phases reduces the expansion resistance of the pores, and accelerates the chemical reaction between $\mathrm{SiC}$ and $\mathrm{O}_{2}$, thereby increasing the level of $\mathrm{SiC}$ oxidation $[24,25]$.
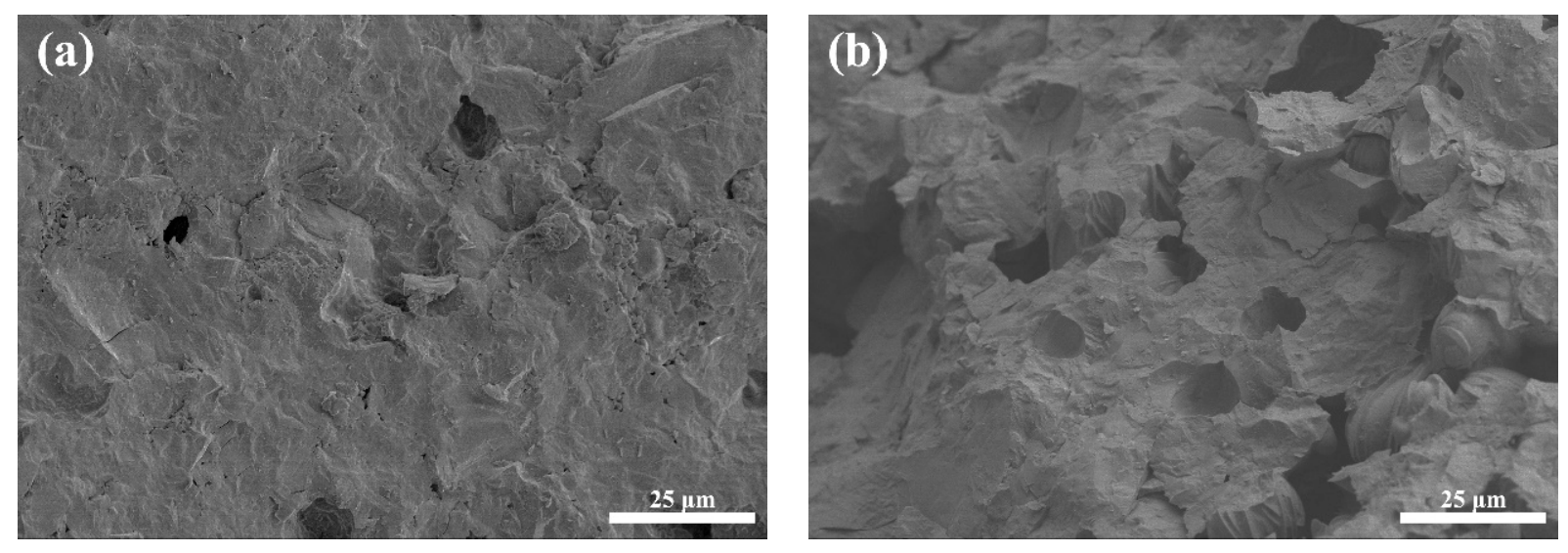

Figure 4. Morphology of BOF slag before and after SiC foaming. (a) Reconstructed BOF slag; (b) Porous reconstructed BOF slag.

The reconstructed steel slag and $\mathrm{SiC}$ foamed porous reconstructed steel slag are tested through MIP. The relationship between the amount of non-wetting liquid entering pores and the continuously increasing pressure are tracked basing on the Washburn equation [26], and the results are shown in Table 4. P is the pressure of the liquid level, $\gamma$ is Surface tension, $\theta$ is contact angle, and $\mathrm{r}$ is radius of curvature.

$$
\mathrm{P}=\frac{-2 \gamma \cos \theta}{\mathrm{r}}
$$

The pore size distribution diagram and the cumulative mercury intrusion curve of BOF slag are shown in Figure $5 a, b$ respectively. The total area of the mercury intrusion curve equals the total volume of the unit mass pores according to the graph. The pore size distribution presents multiple peaks, and the coarse pores increase slightly after SiC foaming, which may be because some small pores combine to form larger pores due to the large dosage of $\mathrm{SiC}$. The total pore volume per unit mass of steel slag increases from $0.1228 \mathrm{~mL} / \mathrm{g}$ to $0.1872 \mathrm{~mL} / \mathrm{g}$, the porosity increases from $21.48 \%$ to $31.79 \%$, the total pore area increases from $14.554 \mathrm{~m}^{2} / \mathrm{g}$ to $26.724 \mathrm{~m}^{2} / \mathrm{g}$, the medium pore diameter increases from $48.4 \mathrm{~nm}$ to $52.4 \mathrm{~nm}$, and the average pore size is reduced from $33.7 \mathrm{~nm}$ to $28 \mathrm{~nm}$, as plotted in Table 5. The reconstructed steel slag after $\mathrm{SiC}$ foaming has a porous structure, which is consistent with the results of the microscopic morphology analysis.

The FBT-5 SSA diameter is used to test the ground steel slag powder separately, and the results obtained are as shown in Table 6: The SSA of the reconstructed BOF slag powder increases with the increase of the $\mathrm{SiC}$ content, when the $\mathrm{SiC}$ content is less than $1.6 \%$. The SSA of the PRS4 group BOF slag powder with a SiC content of 1.6 and a porosity of $31.79 \%$ reached $424.4 \mathrm{~m}^{2} / \mathrm{kg}$. The pore structure of the porous reconstituted steel slag deteriorates and the SSA begins to decrease when the SiC content continues to increase, but it is still higher than that of the unfoamed reconstructed steel slag. The porosity of the reconstructed steel slag after $\mathrm{SiC}$ high-temperature foaming increases, its mechanical strength decreases, and the grinding efficiency is improved. The grindability of the reconstructed steel slag is improved to varying degrees.

The average particle size of the fine powder ground from the PRS4 porous reconstructed steel slag is reduced to $24.36 \mu \mathrm{m}$ compared to $39.96 \mu \mathrm{m}$ of the reconstructed steel slag as shown in Figure 6, which is basically consistent with the SSA test result, and further confirms that the grindability of reconstituted steel slag is improved after high-temperature 
foaming of $\mathrm{SiC}$. This method, which can improve the grindability of BOF slag, is carried out industrially using the residue heat of high temperature molten steel slag. Despite the fact that the foaming process of $\mathrm{SiC}$ releases $\mathrm{CO}_{2}$, it is still relatively environmentally friendly compared to the manufacturing process of conventional cement materials.

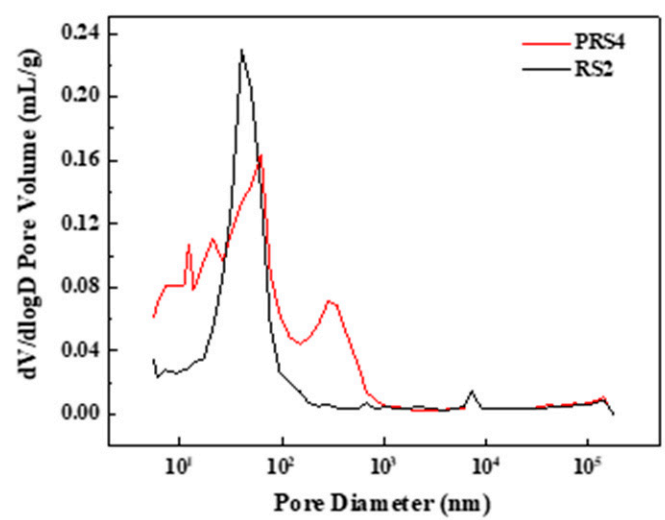

(a)

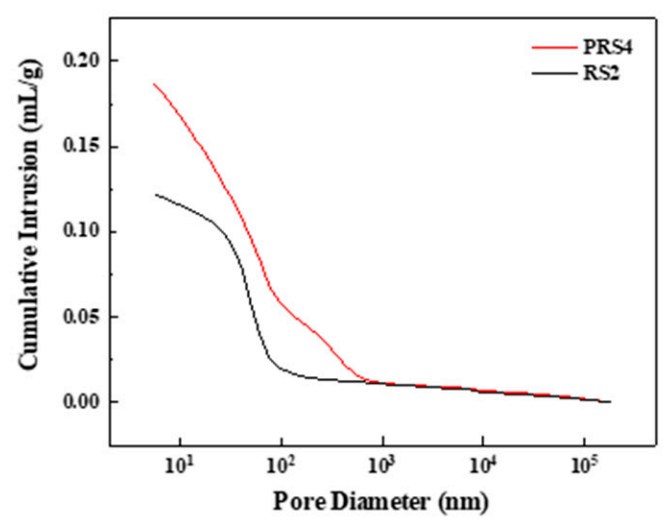

(b)

Figure 5. MIP analysis of porous reconstructed steel slag foaming with SiC. (a) Pore size distribution; (b) Cumulative intrusion.

Table 5. Pore structure changes of reconstructed steel slag before and after $\mathrm{SiC}$ foaming.

\begin{tabular}{cccccc}
\hline Sample & Porosity $(\%)$ & Average Pore Size $(\mathbf{n m})$ & Medium Pore Size $(\mathbf{n m})$ & Total Pore Volume $(\mathbf{m L} / \mathbf{g})$ & Total Pore Area $\left(\mathbf{m}^{2} / \mathbf{g}\right)$ \\
\hline RS2 & 21.48 & 33.7 & 48.4 & 0.1228 & 14.554 \\
PRS4 & 31.79 & 28 & 52.4 & 0.1872 & 26.724 \\
\hline
\end{tabular}

Table 6. SSA of porous reconstructed steel slag with different content of SiC.

\begin{tabular}{cc}
\hline Sample & SSA $\left.\mathbf{~ ( m}^{\mathbf{2}} \mathbf{k g}\right)$ \\
\hline PRS1 & 356.2 \\
PRS2 & 367.7 \\
PRS3 & 389.1 \\
PRS4 & 424.4 \\
PRS5 & 395.6 \\
RS & 354.5 \\
\hline
\end{tabular}

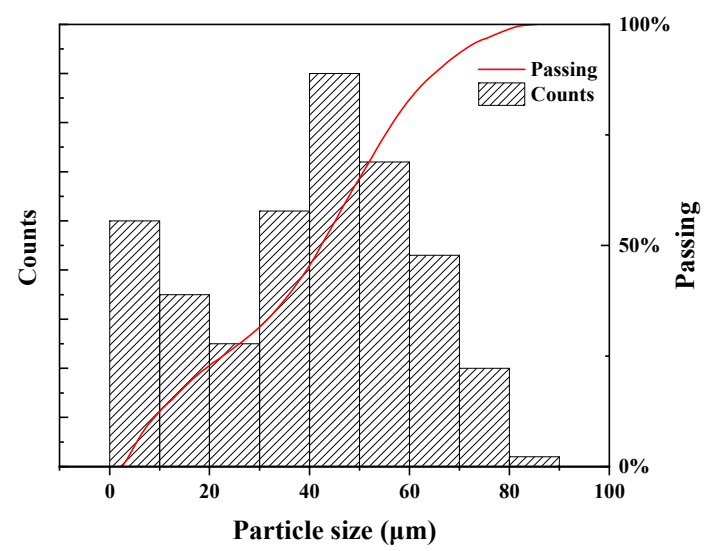

(a)

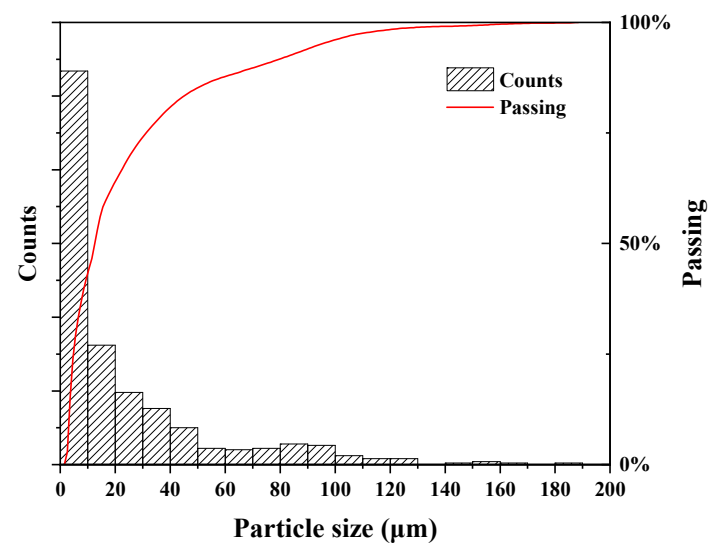

(b)

Figure 6. Particle distribution changes of SiC foaming. (a) Unfoamed reconstructed BOF slag; (b) Porous reconstructed BOF slag. 


\section{Conclusions}

1. The $\mathrm{RO}$ phase in the BOF slag was decomposed when the tempering components were incorporated, and the precipitated $\mathrm{FeO}$ reacts to form $\mathrm{C}_{2} \mathrm{~F}$ and $\mathrm{C}_{4} \mathrm{AF}$, while $\mathrm{MgO}$ partly dissolves in the silicate phase and the ferro-aluminate phase, and partly exists in the form of iron-magnesium spinel.

2. The grindability of the BOF slag was improved, as the content of the $\mathrm{RO}$ phase was reduced. The SSA of reconstituted steel slag increased from $303.1 \mathrm{~m}^{2} / \mathrm{kg}$ of unmodified steel slag to $354.5 \mathrm{~m}^{2} / \mathrm{kg}$ after $10 \mathrm{~min}$ of vibratory grinding, and the average particle size decreased from $51.75 \mu \mathrm{m}$ to $39.96 \mu \mathrm{m}$.

3. The porosity of the reconstructed BOF slag increased after $\mathrm{SiC}$ was added, and reached $31.79 \%$ when the $\mathrm{SiC}$ content was $1.6 \mathrm{wt} \%$. The grindability of the reconstructed BOF slag was significantly improved. The SSA of the reconstructed BOF slag without a foaming agent was increased by $69.9 \mathrm{~m}^{2} / \mathrm{kg}$, and the average particle diameter was reduced by $15.60 \mu \mathrm{m}$. Excess gas was generated when the content of $\mathrm{SiC}$ was too high, the pore structure was destroyed, and an unfavorable impact on grindability was exerted.

4. The findings of this study can be used to inform the development of BOF slag, which can be used in place of cement to reduce the consumptions of natural resources associated with the production of cement clinker.

Author Contributions: Conceptualization, R.X.; data curation, R.X. and J.F.; funding acquisition, P.C. and J.W.; investigation, R.X.; project administration, P.C. and R.L. supervision, P.C., R.L. and C.H.; writing—original draft, R.X.; writing—review \& editing, R.X., R.L. and D.W. All authors have read and agreed to the published version of the manuscript.

Funding: The authors are grateful for the funding provided by the National Key Research and Development Program of China (Project 2019YFC1906202), the National Natural Science Foundation of China (Grant No. 21566008), Guangxi Key Research and Development Plan (Guike AA18242007, Guike AB17129014 and Guike AB19259008), The Independent research project of Guangxi Key Laboratory of Optoelectronic Materials and Devices(20AA-21), and the GuangXi Key Laboratory of New Energy and Building Energy Saving (Guikeneng 19-J-22-3).

Institutional Review Board Statement: Not applicable.

Informed Consent Statement: Not applicable.

Data Availability Statement: Not applicable.

Conflicts of Interest: The authors declare no conflict of interest.

\section{References}

1. Kazemian, A.; Vayghan, A.G.; Rajabipour, F. Quantitative assessment of parameters that affect strength development in alkali activated fly ash binders. Constr. Build. Mater. 2015, 93, 869-876. [CrossRef]

2. Huntzinger, D.N.; Eatmon, T.D. A life-cycle assessment of Portland cement manufacturing: Comparing the traditional process with alternative technologies. J. Clean. Prod. 2009, 17, 668-675. [CrossRef]

3. Pacheco-Torgal, F.; Abdollahnejad, Z.; Camoes, A.F.; Jamshidi, M.; Ding, Y. Durability of alkali-activated binders: A clear advantage over Portland cement or an unproven issue? Constr. Build. Mater. 2012, 30, 400-405. [CrossRef]

4. Kourounis, S.; Tsivilis, S.; Tsakiridis, P.E.; Papadimitriou, G.D.; Tsibouki, Z. Properties and hydration of blended cements with steelmaking slag. Cem. Concr. Res. 2007, 37, 815-822. [CrossRef]

5. Belhadj, E.; Diliberto, C.; Lecomte, A. Characterization and activation of Basic Oxygen Furnace slag. Cem. Concr. Compos. 2012, 34, 34-40. [CrossRef]

6. Wang, Q.; Yan, P.Y. Hydration properties of basic oxygen furnace steel slag. Constr. Build. Mater. 2010, 24, 1134-1140. [CrossRef]

7. Xue, P.; Xu, A.J.; He, D.F.; Yang, Q.X.; Liu, G.Q.; Engstrom, F.; Bjorkman, B. Research on the sintering process and characteristics of belite sulphoaluminate cement produced by BOF slag. Constr. Build. Mater. 2016, 122, 567-576. [CrossRef]

8. Wu, Q.S.; Wu, Y.; Tong, W.H.; Ma, H.E. Utilization of nickel slag as raw material in the production of Portland cement for road construction. Constr. Build. Mater. 2018, 193, 426-434. [CrossRef]

9. Zhang, Z.S.; Xv, L.H.; Yu, G.W.; Tang, W.J.; Saiyin, B.; Sun, P.H.; Hao, H.S.; Zhai, W. Influences of the powder of steel slag and granulated blast furnace slag by mechanical activation. Concrete 2010, 10, 92-94. (In Chinese)

10. Choi, H.; Lee, W.; Kim, D.U.; Kumar, S.; Kim, S.S.; Chung, H.S.; Kim, J.H.; Ahn, Y.C. Effect of grinding aids on the grinding energy consumed during grinding of calcite in a stirred ball mill. Miner. Eng. 2010, 23, 54-57. [CrossRef] 
11. Hou, G.H.; Li, W.F.; Wang, J.G. Difference of grindability and cementitious performance among minerals in steel slag. J. Chin. Ceram. Society 2009, 10, 1613-1617. (In Chinese)

12. Zhao, J.H.; Wang, D.M.; Yan, P.Y.; Zhao, S.J.; Zhang, D.W. Particle characteristics and hydration activity of ground granulated blast furnace slag powder containing industrial crude glycerol-based grinding aids. Constr. Build. Mater. 2016, 104, 134-141. [CrossRef]

13. Zhao, J.; Wang, D.; Yan, P.; Li, W. Comparison of Grinding Characteristics of Converter Steel Slag with and without Pretreatment and Grinding Aids. Appl. Sci. 2016, 6, 237-251. [CrossRef]

14. Chen, K.L. Study on the Activation of Divalent Oxide for Steel Slag and Cementitious Properties. Master's Thesis, Guilin University of Technology, Guilin, China, 2017.

15. Hou, X.K.; He, N.; Yuan, J.S.; Dong, Y.B.; Yang, H.Y. Separation of Divalent Metal Oxides Solid Solution from Steel Slag. J. Chin. Ceram. Soc. 2013, 41, 1142-1150. (In Chinese)

16. Wang, Q.; Zhang, L.A.; Bai, J.R.; Liu, H.P.; Li, S.H. The influence of microwave drying on physicochemical properties of Liushuhe oil shale. Oil Shale 2011, 28, 29-41.

17. Qin, Y.H.; Han, Y.X.; Gao, P.; Li, Y.J.; Yuan, S. Pre-weakening behavior of magnetite quartzite based on high-voltage pulse discharge. Miner. Eng. 2021, 160, 106662. [CrossRef]

18. China Building Materials Company; Zhejiang Chengjian Group Co., Ltd.; China Isosand Co., Ltd.; Beijing Xin'ao Concrete Group Co., Ltd. GB/T 208-2014 Test Method for Determining Cement Density; General Administration of Quality Supervision; Inspection and Quarantine of the People's Republic of China: Beijing, China; Standardization Administration of China: Beijing, China, 2014. (In Chinese)

19. China Building Materials Company. GB/T 8074-2008 Testing Method for Specific Surface of Cement_Blaine Method; General Administration of Quality Supervision; Inspection and Quarantine of the People's Republic of China: Beijing, China; Standardization Administration of China: Beijing, China, 2008. (In Chinese)

20. Doremus, R.H. Transport of oxygen in silicate glasses. J. Non-Cryst. Solids. 2004, 349, 242-247. [CrossRef]

21. Bernardo, E. Micro- and macro-cellular sintered glass-ceramics from wastes. J. Eur. Ceram. Soc. 2007, 27, 2415-2422. [CrossRef]

22. Orts, M.J.; Amorós, J.L.; Escardino, A.; Gozalbo, A.; Feliu, C. Kinetic model for the isothermal sintering of low porosity floor tiles. Appl. Clay Sci. 1993, 8, 231-245. [CrossRef]

23. Bernardo, E.; Cedro, R.; Florean, M.; Hreglich, S. Reutilization and stabilization of wastes by the production of glass foams. Ceram. Int. 2007, 33, 963-968. [CrossRef]

24. Chayasombat, B.; Kato, T.; Hirayama, T.; Tokunaga, T.; Sasaki, K.; Kuroda, K. Oxidation kinetics of single crystal silicon carbide using electron microscopy. J. Ceram. Soc. Jpn. 2012, 120, 181-185. [CrossRef]

25. Kingery, W.D.; Bowen, H.K.; Uhlmann, D.R. Introduction to Ceramics; John Wiley \& Sons: Oxford, UK, 1976.

26. Brugnara, M.; Degasperi, E.; Della, C.V.; Maniglio, D.; Penati, A.; Siboni, S. Wettability of porous materials. II. Can we obtain the contact angle from the Washburn equation? Contact Angle Wettability Adhes. 2006, 4, 143-164. 